\title{
Effect of Targeted Mutation in Collagen $V \alpha 2$ Gene on Development of Cutaneous Hyperplasia in Tight Skin Mice
}

\author{
Robert G. Phelps, ${ }^{1}$ Chihiro Murai, ${ }^{2}$ Shinichiro Saito, ${ }^{2}$ \\ Akira Hatakeyama, ${ }^{2}$ Konstantinos Andrikopoulos, ${ }^{3}$ \\ Kuppuswamy N. Kasturi, ${ }^{2}$ and Constantin A. Bona ${ }^{2}$ \\ ${ }^{1}$ Department of Pathology, ${ }^{2}$ Department of Microbiology, and \\ ${ }^{3}$ Department of Molecular Biology, Mount Sinai School of Medicine, \\ New York, New York, U.S.A.
}

Accepted March 17, 1998.

\begin{abstract}
Collagen $\mathrm{V}$ plays a major regulatory role in the formation of heterotypic fibers of the dermis and cartilaginous tissues as well as in the assembly of extracellular matrix. The $\mathrm{pN} / \mathrm{pN}$ mouse, which is defective in collagen $\mathrm{V} \alpha 2$ gene, exhibits skeletal abnormalities, skin fragility, and alterations in the collagen fiber organization, whereas the TSK/+ mouse, which is defective in fibrillin-1, the major component of microfibrils present in the extracellular matrix, develops cutaneous hyperplasia and autoimmunity. We have studied the role of collagen $\mathrm{V}$ in the
\end{abstract}

formation of heterotypic collagen fibers in $F_{1}$ mice, which are obtained by breeding $\mathrm{pN} / \mathrm{pN}$ with $\mathrm{TSK} /+$ mice. Our results show that $F_{1}$ progeny neither develop cutaneous hyperplasia nor produce anti-topoisomerase I autoantibodies, unlike TSK/+ mice. The diameter of the collagen fibrils in the skin is also comparable to that found in control mice. Thus, the phenotypic changes observed in the TSK mouse could be reversed by genetic complementation with a collagen $\mathrm{V}$-defective mouse.

\section{Introduction}

Mutations in genes coding for extracellular matrix proteins cause a variety of connective tissue abnormalities. Mutations in collagens ( $\mathrm{Col})$, the most abundant and widely distributed matrix macromolecules, can lead to alterations in fibrillogenesis. The concept that collagen fibrils may be formed by the association of products encoded by more than one collagen gene is not new, as the presence of heterotypic collagen fibrils formed by collagen I/V and collagen V/XI fibrils have been described $(1,2)$. It is also known that

Address correspondence and reprint requests to: Dr. Kuppuswamy N. Kasturi, The Mount Sinai Medical Center, Mount Sinai School of Medicine, Department of Microbiology, Box 1124, One Gustave L. Levy Place, New York, New York 10029, U.S.A. Phone: 212-241-9777; Fax: 212-5341684 . the diameter of the heterotypic Col I/V fibrils is determined by the ratio of the two collagens that participate in the formation of these fibrils, which suggests that ColV plays a regulatory role in fibrillogenesis (3). The $\mathrm{pN} / \mathrm{pN}$ mouse, which is obtained by a targeted deletion in the ColV $\alpha 2$ gene, exhibit skin fragility, skeletal abnormalities, and alterations in the collagen fiber organization, which confirm the regulatory role of ColV (4). The tight-skin mouse (TSK), a naturally occurring mutant, develops a generalized connective tissue abnormality that is transmitted as an autosomal dominant trait. The TSK mouse phenotype is characterized by marked hyperplasia of loose connective tissue, thickening of the skin, and development of abnormalities in several internal organs (5-7). The skin thickening in TSK mice results from an excessive accumulation of 
extracellular matrix proteins, such as Col I, Col III, and glycoaminoglycans (5,8-11). More recently, it has been shown that the TSK mouse abnormality is due to a defect in the gene coding for fibrillin-1 (Fbnl) (12,13), major component of the microfibrils present in the extracellular matrix. The relationship between the defect in the Fbnl gene and the accumulation of other extracellular proteins that are neither structurally nor functionally associated is not known.

Although there are striking differences between the two strains in cellular infiltration in dermis, both strains exhibit cutaneous thickening due to accumulation of collagen in the skin. This observation prompted us to investigate whether the phenotypic changes observed in the TSK mouse can be reversed by genetic complementation with a collagen-defective strain such as the $\mathrm{pN} / \mathrm{pN}$ mouse. In this report, we show that the normal phenotype can be restored in $F_{1}$ TSK/+ mutants with $p N /+$ genotype.

\section{Materials and Methods}

Mice

C57BL/6, 129/Sv, C57BL/6 pa/pa, and TSK/+ mice were purchased from the Jackson Laboratory (Bar Harbor, $\mathrm{ME}$ ), and $\mathrm{pN} / \mathrm{pN}$ mice were kindly provided by F. Ramirez (Brookdale Center, Mount Sinai School of Medicine). $F_{1}$ mice were prepared at Mount Sinai Animal Facilities.

\section{Identification of TSK mutants}

Genomic DNAs were prepared from tail biopsies following the procedure previously described (14). Ten micrograms of genomic DNA sample was digested with EcoRI and BamHI, Southern blotted, and hybridized with ${ }^{32}$ P-labeled Fbn 1 polymorphic DNA probe. The mice exhibiting restriction fragment length polymorphism (RFLP) were identified as previously described (13).

\section{Light and electron microscopy}

Skin samples of $4.0 \mathrm{~cm}^{2}$ were removed from the dorsal side immediately below the neck in a manner that minimized stress. The samples were fixed for $16 \mathrm{~h}$ in buffered saline containing formalin, cut into 2- to 3-mm-wide longitudinal strips, dehydrated, and embedded in paraffin according to routine histological methods. The thickness of the skin was determined by measuring it from the top of granular layer to the junction between the dermis and subcutaneous fat on hematoxylin and eosin- stained sections. Skin tissues for electron microscopy were processed following standard techniques, and the diameter of collagen fibrils present in various zones of mid-dermis was determined as previously described (15).

\section{Quantitation of soluble type I collagen in skin}

The content of soluble ColI and ColV in skin samples was determined as previously described (10). Briefly, skin samples from 12- to 15-weekold mice were minced and the soluble proteins were extracted with neutral $\mathrm{pH}$ salt buffer at $4^{\circ} \mathrm{C}$ and dialyzed against $0.5 \mathrm{M}$ acetic acid buffer. The samples were spun at $10 \mathrm{~K}$ for $10 \mathrm{~min}$. The supernatants were digested with pepsin (protein: pepsin, 10:1) and then lyophilized. Both digested and undigested samples were resuspended in SDS-PAGE sample buffer, separated on $4-20 \%$ SDS polyacrylamide gradient gels, and stained with silver stain following the manufacturer's protocol (Bio-Rad). The concentration of collagens was determined by scanning the gel using Adobe Photoshop software and ImageQuant software.

\section{Quantitation of anti-topo I autoantibodies}

The antibody titer of the sera from 12- to 15week-old mice was determined by radioimmunoassay (RIA) and the concentration was calculated by integrating the bound cpm value of sera on the linear region of a standard curve constructed with 3-fold dilutions of monoclonal anti-topo I antibody as previously described (16).

\section{Results and Discussion}

Of $18 F_{1}$ mice that we studied, five exhibited Fbnl RFLP typical of TSK/+ mice, nine were of wild type, and four were unidentified (Fig. 1). Histologically, TSK/+ mice exhibit cutaneous hyperplasia characterized by a progressive increase in the deposition of collagenous material that replaces the superficial and deep dermis, extending around adnexa and the panniculus carnosus with some inflammatory cellular infiltration (Fig. 2A). On the other hand, pN/pN mice showed thinner epidermis and a thickened dermis containing larger-diameter collagen fibrils without cellular infiltration (Fig. 2B). The collagen fibrils were less tightly packed and the space between collagen fibrils was filled with proteoglycans (Fig. 3B). The thickening of dermis observed in $\mathrm{pN} / \mathrm{pN}$ mice is related to the presence of larger-diameter collagen fibers. By contrast, 


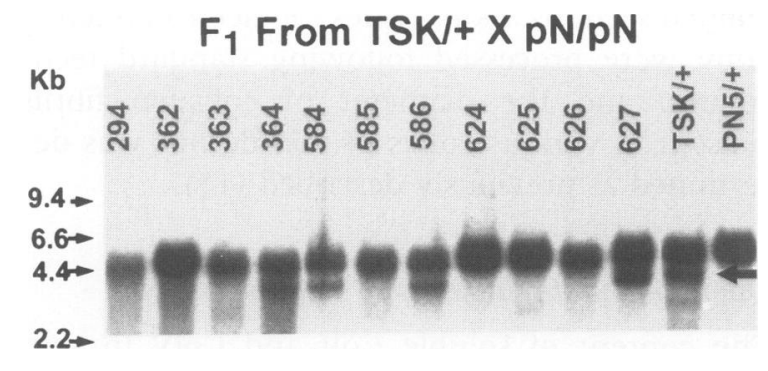

Fig. 1. Identification of Fbn I mutants (TSK/+) among $F_{1}$ mice. Autoradiograph of a representative Southern blot hybridized with the polymorphic Fbnl DNA probe as previously described (13). Arrow shows the position of the polymorphic Fbnl band.

the skin of $\mathrm{F}_{1}$ mice $(\mathrm{TSK} /+\mathrm{pN} /+$ or $+/+\mathrm{pN} /+$ showed normal histology (Fig. 2C, D). The average thickness of skin in $F_{1}$ mice was $(120-150$ $\mu \mathrm{m})$, which is significantly less than that of $\mathrm{TSK} /+$ or $\mathrm{pN} / \mathrm{pN}$ mice, regardless of their Fbn 1 $+1-$ or $+1+$ genotype (Table 1 ), and was comparable to that of $129 / \mathrm{sv}, \mathrm{C} 57 \mathrm{BL} / 6$, and C57BL/6 $\mathrm{pa} / \mathrm{pa}$ mice (10). Electron microscopic examination of sections of TSK/+ skin showed predominance of the small-diameter collagen fibrils exhibiting normal banding (Fig. 3A) as previously described (15). The most important difference between $\mathrm{TSK} /+$ and $\mathrm{pN} / \mathrm{pN}$ is the abundance of large-diameter collagen fibrils in $\mathrm{pN} / \mathrm{pN}$ mice. A similar increase in the mean diameter and irregularity in the shape of collagen fibrils has been reported in the Gravis form of Ehlers-Danlos syndrome (17). SDS gel analysis of pepsindigested collagens extracted from cells cultured from these patients has shown presence of a novel component migrating ahead of the normal $\alpha \mathrm{l}$ chain of collagen $\mathrm{V}(18)$. This alteration is due to the deletion of $54 \mathrm{bp}$ coding six Gly-X-Y triplets in exon 49 of the $\alpha 1$ gene. Thus, it seems that the mutations in $\alpha 1$ or $\alpha 2$ chains of Col V in humans and rodents, respectively, lead to similar phenotypic alterations characterized by an increase in the diameter of collagen fibrils.

In $\mathrm{TSK} /+\mathrm{pN} /+\mathrm{F}_{1}$ mice, the collagen bundles are composed of fibrils with normal periodicity of bands similar to those present in $+/+\mathrm{pN} /+$ mice, although occasionally the fibrils may be separated by more space as in TSK mice (Fig. 3C, D). Histometric analysis of collagen fibrils present in various zones of dermis showed a preponderance of 30- to 80-nm diameter fibrils in TSK mice, in contrast to that of $>110-\mathrm{nm}$ diameter fibrils in $\mathrm{pN} / \mathrm{pN}$ mice (Fig. 4). Presence of small-diameter fibrils is an
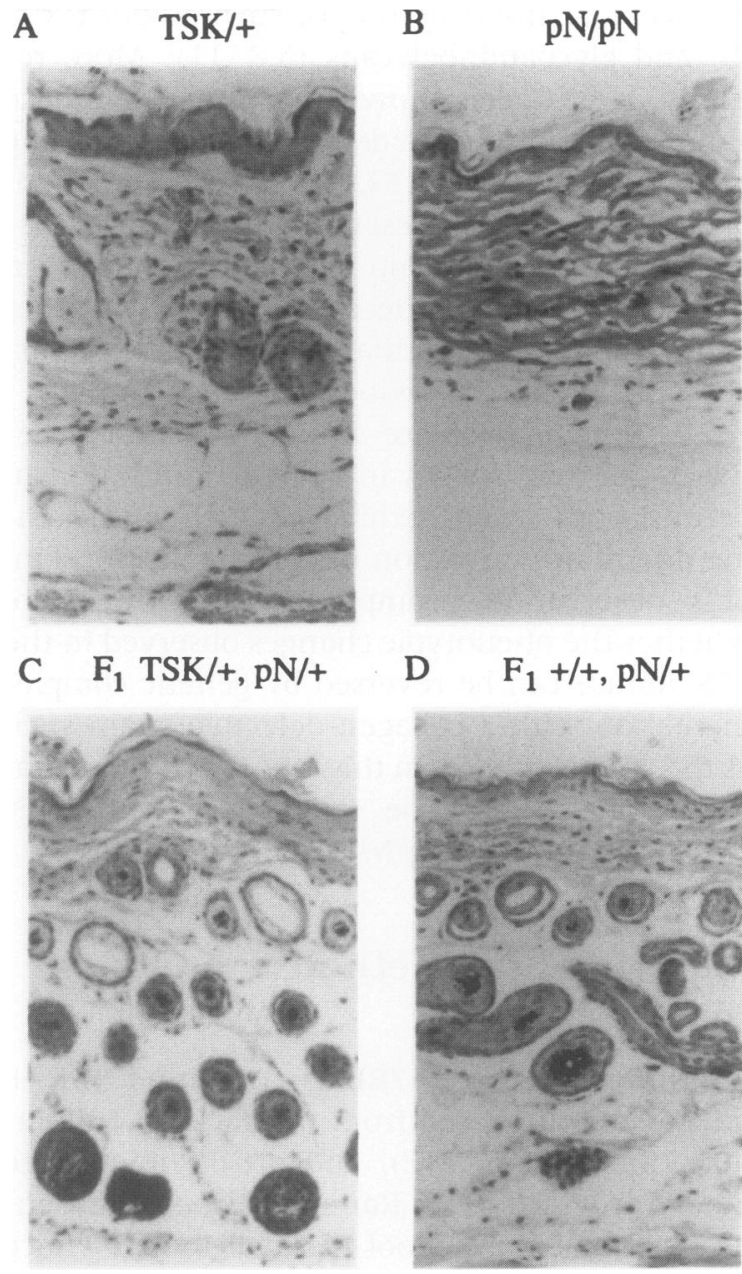

Fig. 2. Light microscopy of skin samples from 3- to 5-month-old mice. $\mathrm{TSK} /+(\mathrm{A}), \mathrm{pN} / \mathrm{pN}(\mathrm{B})$, $\mathrm{TSK} /+, \mathrm{pN} /+(\mathrm{C})$, and $+/+, \mathrm{pN} /+(\mathrm{D})$. (A-D: hematoxylin and eosin $\times 10$ ).

indication of ongoing collagen synthesis (4). On the other hand, both TSK $/+\mathrm{pN} /+$ and $+/+\mathrm{pN} /+$ mice $\left(\mathrm{F}_{1}\right)$ showed principally $80-$ to $110-\mathrm{nm}$ diameter fibrils as in control C57BL/6 pa/pa mice (15). Thus, there were no histological or ultrastructural abnormalities observed in the collagen fibrils of TSK/+, pN/+ mouse skin. Soluble ColI and ColV content in the skin of $F_{1}$ mice was also significantly $(p<0.05)$ lower than that of TSK $/+$ mice (Table 1), which shows restoration of normal skin thickness. Our study provides further evidence suggesting that Colv plays an important role in the formation of extracellular matrix in vivo and demonstrates for the first time that mutant ColV protein contributes to rescue of the normal skin phenotype in TSK mice. The mechanisms that might be involved in this process are complex. Although the deletion of ColV $\alpha 2 \mathrm{~N}$-terminal peptide does 


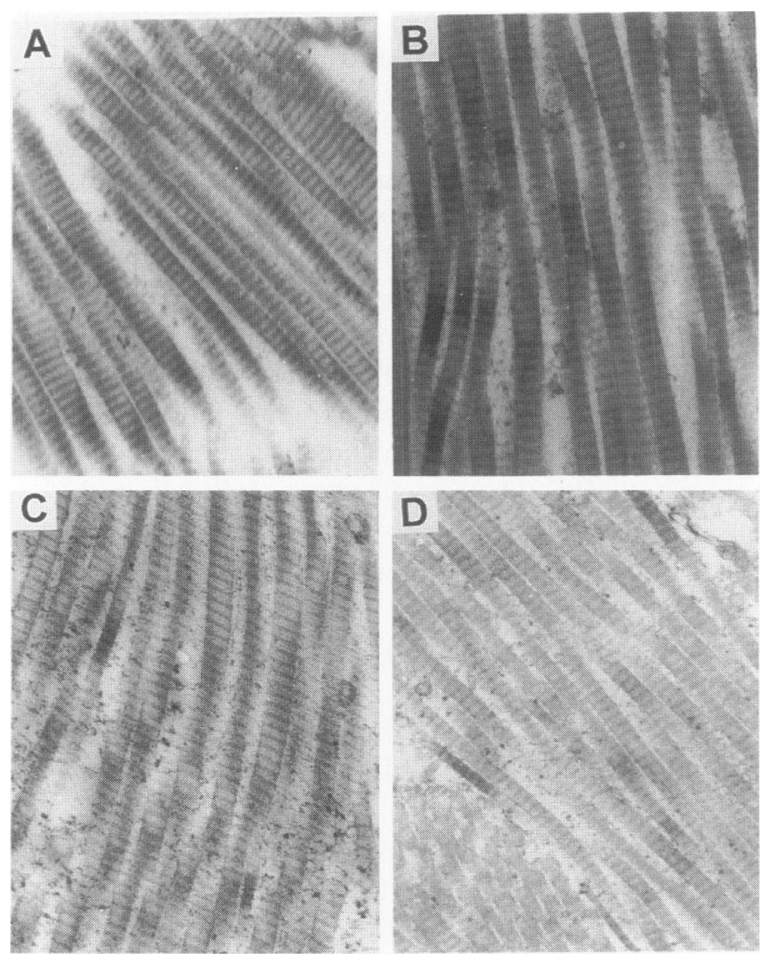

Fig. 3. Electron microscopy of collagen fibrils present in the mid-dermis $(\times 10 \mathrm{~K}) . \mathrm{TSK} /+(\mathrm{A})$, $\mathrm{pN} / \mathrm{pN}(\mathrm{B}), \mathrm{TSK} /+\mathrm{pN} /+(\mathrm{C})$, and $+/+\mathrm{pN} /+$ mice (D).

not preclude the association of mutant ColV chain with ColI to form fibrils, this may alter the growth of collagen fibrils mediated by ColV. It is possible that either the heterotypic fibers formed by ColI and mutant Colv fibrils are more accessible to proteolytic enzymes or the deposition of excess ColI and ColIII fibrils on ColV scaffolding is altered, leading to their easier accessibility to metaloproteinases and degradation.

Although both $\mathrm{pN} / \mathrm{pN}$ and TSK mice exhibit cutaneous thickening (Fig. 2 and Table 1), there are striking differences between these two mutant strains: (1) a lack of cellular infiltration in the dermis of $\mathrm{pN} / \mathrm{pN}$ mice; (2) a more pronounced disorganization of microfibrils in TSK/+ mice (5); and (3) predominance of small-diameter collagen fibrils in $\mathrm{TSK} /+$ mice but largerdiameter fibrils in $\mathrm{pN} / \mathrm{pN}$ mice. It is also notable that $\mathrm{TSK} /+\mathrm{pN} /+\mathrm{F}_{1}$ mice do not show any significant increase in the titer of anti-topo I autoantibodies as in TSK/+ mice (Table 1). This observation strengthens the hypothesis that autoantibodies specific for self antigens such as topo I, which are found in humans afflicted with systemic sclerosis and in tight skin mice $(16,19,20)$, are the consequence of alterations in the matrix proteins. It is likely that the effect of TSK mutation in mice bearing $T S K /+p N / p N$ genotype may be more pronounced than in Fl progeny. However, among the 48 backcross progeny that we studied, no $T S K /+p N / p N$ genotype was found.

Although our current study focused on the alterations exhibited in the skin of these mice, because TSK mice also exhibit cardiac hypertrophy (7) and pulmonary emphysema (6), it would be important to study whether a similar restoration of normal phenotype is possible in other affected organs as well. The results presented here have 2-fold importance. First, they show that the phenotype resulting from a spontaneous mutation in the fibrillin-1 gene, which leads to the abnormal synthesis and deposition of ColI and ColIII, can be rescued by genetic comple-

Table 1. Phenotypic characteristics of $F_{1}$ mice

\begin{tabular}{|c|c|c|c|c|c|c|c|c|}
\hline \multirow{2}{*}{$\begin{array}{l}\text { Mouse } \\
\text { Strain }\end{array}$} & \multirow[b]{2}{*}{ No. } & \multirow[b]{2}{*}{ Genotype } & \multicolumn{2}{|c|}{ Frequency } & \multirow{2}{*}{$\begin{array}{c}\text { Skin } \\
\text { Thickness } \\
(\boldsymbol{\mu m})\end{array}$} & \multicolumn{2}{|c|}{$\begin{array}{c}\text { Percent of } \\
\text { Soluble Collagen }\end{array}$} & \multirow{2}{*}{$\begin{array}{c}\text { Serum Anti-topo I } \\
\text { Autoantibodies } \\
(\mu \mathrm{g} / \mathrm{ml})\end{array}$} \\
\hline & & & Expected & Observed & & Col I & Col V & \\
\hline TSK/+ & 5 & TSKI+ & 5.0 & 5 & $239 \pm 6$ & $12.7 \pm 0.6$ & $5.1 \pm 1.5$ & $10.3 \pm 0.80$ \\
\hline $\mathrm{pN} / \mathrm{pN}$ & 3 & $p N / p N$ & 3.0 & 3 & $210 \pm 13$ & $8.1 \pm 1.7$ & $2.9 \pm 0.1$ & $3.6 \pm 0.10$ \\
\hline \multirow[t]{3}{*}{$\mathrm{F}_{1}$} & 18 & $T S K I+, p N /+$ & 9.5 & 5 & $123 \pm 27$ & $10.3 \pm 3.3$ & $3.0 \pm 1.4$ & $4.2 \pm 2.0$ \\
\hline & & $+I+, p N /+$ & 9.5 & 9 & $107 \pm 21$ & $9.7 \pm 2.9$ & $2.3 \pm 0.5$ & $5.7 \pm 3.1$ \\
\hline & & $\mathrm{ND}, p N /+$ & - & 4 & $97 \pm 14$ & $8.4 \pm 3.7$ & $2.8 \pm 1.3$ & - \\
\hline
\end{tabular}

$\mathrm{F}_{1}=\mathrm{TSK} /+\mathrm{X} \mathrm{pN} / \mathrm{pN}$ mice; \pm values are means $\pm \mathrm{SD} ; \mathrm{ND}$, TSK genotype was not determined as DNA from these mice were not extracted. 


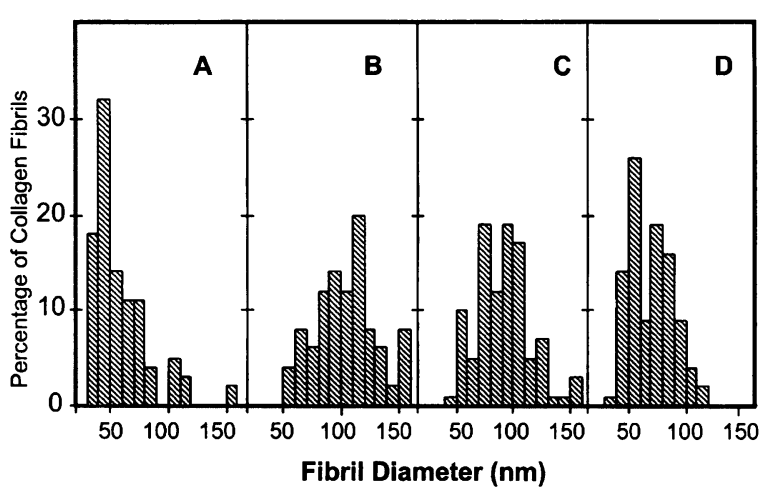

Fig. 4. Histogram showing the distribution of the diameter of collagen fibrils present in the mid-dermis in four strains of mice. $\mathrm{TSK} /+(\mathrm{A})$, $\mathrm{pN} / \mathrm{pN}(\mathrm{B}), \mathrm{TSK} /+\mathrm{pN} /+(\mathrm{C})$, and $+/+\mathrm{pN} /+(\mathrm{D})$.

mentation with a strain having a mutation in the $\alpha 2$ ColV gene. Second, the presence of $50 \%$ abnormal ColV fibrils in $\mathrm{F}_{1}$ mice can significantly alter fibrillogenesis or the fiber formation.

\section{Acknowledgments}

We thank Dr. F. Ramirez for kindly providing the $\mathrm{pN} / \mathrm{pN}$ mice and mouse fibrillin-1 cDNA clones, and for useful discussions. This work was supported by NIH grant AI-24671.

\section{References}

1. Birk DE, Silver FH, Treistad RL. (1991) Matrix assembly. In: Hay ED (ed). Cell Biology Extracellular Matrix. Plenum Press, New York, pp. 221-254.

2. Kivirikko K. (1993) Collagens and their abnormalities in wide spectrum of diseases. Ann. Med. 25: 113-126.

3. Birk DE, Fitch JM, Barbiarz JP, Doane KJ, Linsenmayer TF. (1990) Collagen fibrillogenesis in vitro by interaction of types $\mathrm{I}$ and $\mathrm{V}$ collagen regulates fibril diameter. J. Cell Sci. 95: 649-657.

4. Andrikopoulos K, Liu K, Keene DR, Jaenisch R, Ramirez F. (1995) Targeted mutation in the collagen $5 \alpha 2$ gene reveals a regulatory role for type V collagen during matrix assembly. Nat. Genet. 9: 31-36.

5. Green MC, Sweet HO, Bunker LE. (1976) Tightskin, a new mutation of the mouse causing excessive growth of connective tissue and skeleton. Am. J. Pathol. 82: 493-512.

6. Szapiel SV, Fulmer JD, Hunninghake GW, Elson NA, Kawanami O, Ferrans VJ, Crystal RG. (1981) Hereditary emphysema in the tight-skin mouse. Am. Rev. Respir. Dis. 123: 680-685.

7. Osborn TG, Bashey RI, Moore TL, Fischer VW. (1987) Collagenous abnormalities in the heart of tight-skin mouse. J. Mol. Cell. Cardiol. 19: 581-587.
8. Osborn TG, Bauer NE, Ross SC. (1983) The tightskin mouse: Physical and biochemical properties of the skin. J. Rheumatol. 10: 793-796.

9. Jimenez SA, Williams CJ, Meyers JC, Bashey R. (1986) Increased collagen biosynthesis and increased expression of type I and type III procollagen genes in tight-skin (TSK) mouse fibroblasts. J. Biol. Chem. 261: 657-662.

10. Hatakeyama A, Kasturi KN, Wolf I, Phelphs RG, Bona CA. (1996) Correlation between the concentration of serum antitopoisomerase I autoantibodies and histological and biochemical alterations in the skin of TSK mice. Cell. Immunol. 167: 135-140.

11. Rosenberg GT, Ross SC. (1984) Glycosaminoglycan content in the tight-skin mouse. J. Rheumatol. 10: 793-796.

12. Siracusa LD, McGrath R, Ma Q, Moskow JJ, Manne J, Christner PJ, Buchberg AM, Jimenez SA. (1996) A tandem duplication within the fibrillin 1 gene is associated with the mouse tight skin mutation. Genomic Res. 6: 300-317.

13. Kasturi KN, Hatakeyama A, Murai C, Gordon R, Phelps RG, Bona CA. (1997) B cell deficiency does not abrogate development of cutaneous hyperplasia in mice inheriting defective fibrillin-1 gene. $J$. Autoimmun. 10: 505-517.

14. Laird PW, Zijderveld $K$, Linderts $M$, Rudnicki A, Jaenisch R, Berns A. (1991) A method of preparing genomic DNA. Nucleic Acids Res. 191: 4293.

15. Phelps RG, Shibata S, Daian C, Fleischmajer R, Bona CA. (1993) Induction of skin fibrosis and autoantibodies by infusion of immunocompetent cells from tight-skin mice into $\mathrm{C} 57 \mathrm{BL} / 6 \mathrm{pa} / \mathrm{pa}$ mice. J. Autoimmun. 6: 701-718.

16. Muryoi T, Kasturi KN, Kafina MJ, Cram DS, Harrison LC, Sasaki T, Bona CA. (1992) Antitopoisomerase I monoclonal autoantibodies from scleroderma patients and tightskin mouse interact with similar epitopes. J. Exp. Med. 175: 1103-1109.

17. Vogel A, Holbrook KA, Steinmann B, Gitzelmann R, Byers PH. (1979) Abnormal collagen fibril structure in the Gravis form (type I) of EhlersDanlos syndrome. Lab. Invest. 40: 201-206.

18. Nicholls AC, Oliver JE, McCarron HG, Harrison JB, Greenspan DS, Pope FM. (1996) An exon skipping mutation of a type $\mathrm{V}$ collagen gene (Col $5 \mathrm{Al}$ ) in Ehlers-Danlos syndrome. J. Med. Genet. 33: $940-946$.

19. Shero JH, Bordwell B, Rothfield NF, Earnshaw WC. (1986) High titers of autoantibodies to topoisomerase I (Scl-70) in sera from scleroderma patients. Science 231: 737-740.

20. Muryoi T, Kasturi KN, Kafina MJ, Saito Y, Usuba O, Perlish JS, Fleischmajer R, Bona CA. (1991) Self reactive repertoire of tight skin mouse: Immunochemical and molecular characterization of anti-topoisomerase I autoantibodies. Autoimmunity 9: 109-119. 